\title{
Role of Real Estate Investment Trusts (REITs) in a Mixed Asset Portfolio: A Review of Literature
}

\author{
Daniel Nyachiro ${ }^{1}$ and Ambrose Jagongo $(\mathrm{PhD})^{2}$ \\ ${ }^{1}$ Department of Accounting and Finance, School of Business, Kenyatta University, Kenya \\ ${ }^{2}$ Department of Accounting and Finance, School of Business, Kenyatta University, Kenya
}

\begin{abstract}
Extant studies on the role of REITs is a multi-asset portfolio have resulted to diverse and sometimes contradictory conclusions. The previous research finds send mixed signals to investors on the role of this investment vehicle in Kenya being a new structure. This study sought to analyze and critique empirical studies in this subject area since inception to date in the context developed markets of UK, USA, Australia and Malaysia. This study established that over the long run REITs provide diversification benefits and returns to a mixed asset portfolio. The study also found that REITs are highly correlated to small-cap equities in the short run and to behave more like direct real estate in the long run. Likewise, the study found that REITs market returns seem to be systematically related to returns to both stock and bond market. Based on this review, the study recommends that investors should consider allocating REITs to a mixed asset portfolio to diversify returns to both bond and equities and also to exploit inefficiencies in other asset markets. In addition investors should avoid purchasing REITs during financial distress. Whether these results can be replicated in Kenyan Market is an area of further study.
\end{abstract}

Key Words: REIT, listed real estate, direct real estate, Diversification, mixed asset portfolio, Cointegration

\section{INTRODUCTION}

A REIT is real estate security floated by a public traded company whose core business is to own, develop and manage a variety of properties. A REIT is required by the tax code to hold most (75\%) of their assets in income producing properties, to generate most of their income (75\%) from property rent and distribute at least $90 \%$ of their returns in form of dividends to the investors. According to The National Association of Real Estate investment Trust (NAREIT) a REIT is 'a company that engages in financing of real estate or owning and in most cases operating income producing properties. REITs also enable investors to diversify their real estate holding through purchase of property share in a similar manner to other industries (NAREIT, 2015). The main objective of REITS is to offer an after tax return similar to direct investment in property with an advantage of risk diversification. REITS can be classified into Equity REIT, mortgage REIT or Hybrid REIT. Equity REITS invest and purchase properties and in most cases invest in commercial properties and lease these structures out to tenants thereby making income through collection of rents and sale of the properties they own in the long run. Mortgage REITs principally invest in mortgages or investment securities which are tied to commercial or residential properties (NAREIT 2015).They operate by providing finance in terms of loan to mortgage owners or by purchase of existing mortgage- backed securities thus making profit through the sales of the mortgages or the interest earned from these investments.

The debate on the role of REITs in a mixed asset portfolio has emerged following the operationalization of the Capital Markets Collective Investment Scheme Act 2013 in Kenya .According to Mueller and Mueller (2003), REITs should be influenced by the factors that affect direct real estate like the normal supply and demand fluctuations. However there is a combination of reasons that may trigger increased funds inflow and the investor's interest in REIT sub-sector of real estate market. These factors include the limitations on direct real estate in terms of dividend payments, illiquidity, heterogeneity, large lot size and high transaction cost associated with real estate transactions. Investment in REITs is frequently viewed as a vehicle for participating in the larger real estate market without suffering the disadvantages of direct real estate mentioned earlier. However the debate on the risk- return characteristics of REITs and other asset classes had not been conclusive. The main issue is whether REIT return reflect the underlying direct property and offer potential for portfolio diversification or whether their returns are dominated by other asset classes, bond and equities. The previous literature findings are inconsistent and varying depending on where the study was done, the methodology applied and the time period under consideration. Various studies in USA, UK, Australia and Malaysia have documented various advantages of REITs over other investment vehicles in a mixed asset portfolio. According to Myer \& Webb (1993) and Stephen \& Lee (2008) USA REITs are relatively lowly correlated to US stocks which has supports the case for led REITs diversification benefits in a multi asset portfolio.Lizieri (2003) found evidence to support REITs in a mixed asset portfolio because of favorable risk adjusted benefits, inflation hedging capabilities and low correlation to other financial assets. In contrast Kok and Khoo(1995)and Newell, 
Ting \&Acheampong (2002) found REITs to be an ineffective indirect property investment with unfavorable risk adjusted returns.

The aforementioned inconsistencies in the previous studies together with the limitednature of academic studies on REITs in Africa motivated the current study. The government of Kenya has made strides towards listed real estate (REITs by operationalizing REITs regulation in 2013.Despite evidence of proliferation of REITs in other countries, the popularity and acceptance of REITs as an investment vehicle is very low from both individual and institutional investors. Therefore there is need for investors and market participant awareness on the benefits that may accrue from including REITS in a mixed asset portfolio. This study therefore strives to critique the extant empirical literature from 1960 to 2015 in the context of US, Australia, UK and Malaysia markets in order to achieve four objectives:

i) To compare REITs risk-return characteristics to direct real estate over time.

ii) To establish consistency of REITs return correlation with other financial assets over the years.

iii) To determine the benefits of adding REITs a mixed asset portfolios.

iv) To establish the benefits of adding REITs in a mixed asset portfolios comprising direct real estate.

In view of this study we draw conclusion and implication of allocating REITs in a mixed asset portfolio as they may be applicable in Kenya. This will assist investor's engaged in the investment process in allocation decisions into REIT sector. The study will have impact on investment decisions of property analysts, policy makers and academics through extraction of experiences of the developed market that may be used in their future endeavors in this subsector.

\subsection{Evolution of REITs in Africa}

The first REIT structure was introduced by the US Congress in 1960s under the REITs Act 1960 to enable small investors invest in income producing properties in large scale. A few years later the first REIT was established. The main objective of REITs was to provide asset liquidity and encourage benefits of real estate growth to small investors. Geltner and Miller (1991) noted that The US REITs were passive investment vehicle that provided a liquid way of investing in a diversified portfolio of properties and achieve real estate development profits. As noted by Ghosh et al. (1996) and Ziering et al (1997), the US REITs had a number of structural changes through change of laws and regulations. Prior to 1986, the US REITs was not allowed to operate or manage own property. Subsequent to Tax reforms Act, 1986, tax restrictions were relaxed and REITs could manage own properties with greater flexibility (Cannon and Vogt, 1995). In the early 1990s there were fundamental changes that led acceptance of umbrella partnership REITs (UPREIT).

In Africa the first REIT regulation was established in Ghana in 1994 by the Securities and Exchange Commission of Ghana.(SECG).Subsequently HFC bank launched the first REIT Company the only one existing ever since. The bank had previously used various collective investment schemes as well as corporate bond to finance mortgage lending. Nigeria followed suit in 2007 when the Nigeria's Securities and Exchange Commission (NSEC) operationalized REIT regulation. However the first successful REIT was launched in 2008 which helped Union Homes Hybrid REITS raise N50 million. By 2015 there were only three REITS in Nigeria securities and Exchange market. In South Africa the first REIT regulation was established in 2013.However the listed real estate market has existed since 1969.Prior to the launch of REITs regulation in line with international standards, Johannesburg Securities and Exchange(JSE) traded property unit trusts(PUTs) and property loan stock companies (PLSs) .These real estate investment vehicles were established to allow both individual and institutional investors venture in property market and were adopted by the REITs regulatory framework (JSEC). According to South African REIT association (SARA), as at the end of 2016, there were 33 domestic REITS in South Africa and 3 international REITs with a combined capitalization of more than R450 billion (\$32 billion).

In Kenya REITs Regulation Capital Markets Authority (CMA) Collective Investment Schemes came into effect in December 2013 but it officially began trading in December 2015 on the Alternative Investment market (AIM) segment of NSE. There are two types of REITs trading in NSE bourse the income REIT (I-REIT) and development REIT (D-REIT). Kenya has so far listed only two REITS Fusion REIT and Fahari REIT) .With these developments, Kenya became the fourth Africa country to enact REITS regulations alongside South Africa, Ghana and Nigeria.

\section{Empirical Literature}

This section will review the empirical literature under four heading s(1) Comparison of REITS and direct real estate (2) integration of REITs and stocks and bond (3) inclusion of REITs in a mixed asset portfolio and (4) allocating REITs to a multi asset portfolio with direct real estate. 


\subsection{Comparison of REITs and Direct Real Estate}

Capital markets participants continue to debate on the respective benefits of owning REITs versus direct real estate and whether or how effectively public real estate equities can act as a substitute for owning direct property. It's expected that the REITs performance will be influenced by factors affecting direct real estate because REITs cashflow are derived from the underlying real estate. Direct real estate offer among other benefits tangibility with low volatility, attractive income inflow in terms of dividends and long term capital appreciation (Fisher and Sirman (1994); Gilberto (1992); Webb et al (1988) and Stephen lee (2003). On the other hand direct real estate has its own disadvantages: illiquidity which calls for expert management and lumpiness which requires huge amount of capital outlay to build a diversified portfolio. This therefore implies that it's only realistic to high net worth investors who can easily build a diversified portfolio in real estate. To overcome these disadvantages, institutional and individual investors in the long term take long positions in REITs than direct real estate i.e. REITs can provide alternative investment vehicle to direct real estate without exposure to the stated disadvantages (Stephen lee 2002).However Mueller \& Mueller (2003) found evidence that REITs characteristics have not replicated direct real estate partly because (1), NAREIT Index, a proxy for REIT is largely composed of retail, multifamily and healthcare properties while NCREIF, a proxy for direct real estate, mainly consist of industrial, office and retail properties and (2) REITs follow a different return generating process from that of direct real estate.

According to Moss \& Baum (2012), REITs structure as compared to direct real estate has different pricing mechanism; liquidity attributes as well as leverage qualities. Gilberto (1990) in examining the comparison of equity REITs and private real estate found a common real estate factor that influence listed real estate sector that doesn't drive other financial assets. According to the author bond and stock performance movement significantly drive equity REITS. In their study on Malaysian securitized estate markets, Khok and Koo (1995), Lee \& Ting (2009) and Newell et al. (2002) found evidence that securitized real estate provides unfavorable risk adjusted returns. This was supported by Hamzah and Rosali (2006) who found evidence that Malaysian REITs only outperformed the market in the periods of financial crisis in Asia. According to Mueller \& Mueller (2003) between 1997 and 2002 REITs behaved more like private market real estate. They attributed this to changes in tax regulations (REITS modernization Act, 1999 and revenue reconciliation Act, 1993). Yunus et al. (2012) reported cointegration between REITS and direct real estate in the UK, Australia and not in the US. They found that REITS and direct real estate exhibit similar response to market shocks and that I-REIT sector return are neither influenced by common stock nor direct real estate markets. According to Moss \& Baum (2013) in the long term listed securities (REITs) returns were strongly linked to direct market than the stock market. According to Ang, Nabar\& Wald (2013) the two investments have different components over the shortand medium-term although over the full real estate cycle, the differences tend to converge and both investments portray similar characteristics. These authors however found that listed real estate offers a well sought after alternative to direct real estate which manages to avoid this disadvantage of illiquidity and capital investment. Oikarinen et al. (2011) reported cointegration between US direct real estate and REITS return series and no cointegration between REITs and stock market returns.

According to Crowe \&Krisbergh (2010) listed real estate delivers performances comparable to those from investing in direct real estate portfolios. This was supported by Oikarinen\&Hoesli (2012) who found that REITs and direct real estate are to be comparable in the long term despite the shorter term differences. They supports the case for holding listed real estate as an alternative investment to private market real estate. Similarly, Oikarinen,Hoesli and Serrano (2013) concluded that in the US, REITs plays an important role especially for smaller investors by allowing them access to segments of the market which require more capital. The authors further contend that listed real estate also allows for a quicker access to the market avoiding the long time required for any direct real estate transaction. In this course larger investors will also find it useful to use listed real estate when building portfolios in order to better manage the exposure to different segments of the market and efficiently exploit different stages of the property cycle. According to CBRE research (2012) in long term investment horizon public real estate outperform direct real estate and act as an efficient proxy for private market real estate and the two investments vehicles behave in comparable way.

\subsection{REITsCointegrationwith Stock and Bond Market}

Traditionally real estate has been considered a good diversification tool for a stock portfolio because of the perceived low and sometimes negative correlation with stock markets (Ling and Naranjo 1999). While real estate investment have yielded lower returns than stock, their risk has been lower. These authorsfound that commercial real estate markets were integrated with exchange traded equities and the degree of integration increased during the 1990s but diminished with the use unsmoothed returns to build a real estate portfolio. This was supported by Li \& Wang (1995) and Liu \& Mei (1992) who found evidence that REITs returns are cointegrated with the equitymarket.According to Canover et.al (2002); Claytonn\&Macknnon (2003) and Chandrashekaran (1999) REITs characteristics have switched from large stocks to small caps. These authors 
observed that in the 1990s REITS gradually emulated the characteristics of unsecuritised underlying asset and become less dependent on the stock market. This argument is supported by Mueller et al., Liang \&Mcintosh (1994), Clayton and Mackinnon (2001) and Stevenson (2001) who found evidence to conclude that performance of REITS replicated the small cap equity than growth and general equity. Clayton and Mackinnon (2001) also found substantially declining sensitivity of REITs to stock over the study period and REITs displayed similar characteristics to direct real estate. Ziering et al. (1999) reported declining correlation between REITS and Stocks towards the late 1990s. Correlation dropped from 0.8 in the early 1990s to around 0.16 as at end of 1996.This result indicate that REITs can offer diversification benefits but it depends on the periods of investment. This study however did not show the factors determining the declining correlation. According to Glascock \&Ghosh (2000) and Glascock (2000) prior to 1992 REITs displayed bond like characteristics but stock-like returns after 1992 because of rising interest of ownership from institutional investors. Likewise Stephen lee (2006) and Moss and and Baum (2013) noted a change in characteristics of REITs where REITS's sensitivity to stock market diminished in the 1990s but was reversed in the new millennium (Stephen lee,2006) and REITS behaved similar to direct real estate after 1992(Moss and Baum,2013).

In Australia ,Newell \&Acheampong (2001) and Newell (2005a, 2005b), found evidence of declining correlation between Australian LPT and the stock market with bond becaming the most dominant part of Australian LPTs performance. However Newell (2005a) found a small contribution of real estate on the volatility of LPTs. Similarly Newell et al. (2007) found that in Hong Kong stocks contributed a greater proportion of company's volatility as compared to real estate .Myer \& Webb (1993) and Moss \& Baum (2013) observed that REITs experience significantly higher levels of volatility.Clayton \&Mackinnon (2003) found that US REITs volatility was correlated to large cap stocks but the impact diminished during the period of study. The authors found small caps, bond and direct real estate to be driving volatility. In their study, Cotter\& Stevenson (2006) found that the relationship between EREITs and stock market returns increased between, 1999-06. Using longer data periods Case et al (2010), reported similar results. In contrast to the above discussion Wilson \&Okunev (1996),Wilson et al (1998) and Nelling\&Gyourko (1998) found no evidence of REITS cointegration with the stock market both in domestic and international markets. They found evidence of nonlinear dependence between these markets. (Stephen lee (2006) attributed this to the evolution of REITs over time whereby REITs behave more like value stock rather than growth stock.

According to Sanders $(1996,1998)$ and Chan et al. (2003) high yield corporate bond has the greater power to influence EREIT return than government bond despite the unexplained variations in REITs that cannot be diversified away. This is supported by Allen et al (2000) who reported that interest plays a greater role in driving REITs prices. In contrast, Hemel et al. (1995) found evidence that REITs are closer to bond than stock because of low correlation between REITs and interest rates than the government bond as represented by S\&P 500 .according to Ling \&Naranjo $(1997,1998)$ in the study of systematic determinants of real estate returns, growth in consumption, expected inflation and interest rates have influence on real estate returns which affect all the asset classes. This was partly supported by Cheong et al (2006) who reported that in the long run REITs are cointegrated with both long run interest rates and stock. On the other hand Swanson et al (2002) reported that sensitivity of REITS to interest rate declined after 1993. Glascock \&Ghosh (2002) found that prior to 1992 REITs portrayed bond like returns characteristics but stock-like characteristics after 1992 because of increased institutional investor's ownership.

\subsection{REITs in A Mixed Asset Portfolio}

The role of REITs in a mixed asset portfolio has extensively been examined in the UK, USA, Canada, Australia and Malaysia. According to Moss \& Baum (2013) the effect of an asset on a portfolio's risk and return is either to increase the returns of the portfolio at the same risk level or reduce the risk while offering the same return. According to Kuhle (1987) inclusion of REITs in a multi asset portfolio has little improvement. The author found that EREITS does not improve Sharpe performance of a portfolio consisting common stocks only and there is no difference in the performance of a portfolio of stock without REITs and that with REITS. This was supported by Nelling and Gyourko (1996) and Paladino Mayo (1998) who reached the same conclusion that REITs do not significantly improve stocks performance. According to Mueller et al (1994) inclusion of REITs in a multi asset portfolio adds value but its time dependent. These authors found that REITs were considerably valuable between 1978-80 and 1990-93 but not between 1980 - 1990.This was attributed to strong positive correlation between EREITS and small caps and S \&P (500) but low correlation with bonds. According to Ziering\&Mcintosh (1997) direct real estate and REITs display low correlation with both bond and stock which led to their conclusion that REITs provide diversification benefits as well as hedging inflation. In contrast Glascock et al (2000) found no diversification benefits because REITs tend to be integrated with the general market. This was supported by Mueller, Pauley and Morill (1994) who reported that REITs have the same returns as small Cap stocks but were located in the lower risk portion of the efficient frontier. This was attributed to the fact REITs volatility was nearly a third of the small cap stocks. 
According to Ting (2002) and Lee \& Ting (2009) Malaysian securitized real estate performed poorly and there was no evidence of diversification potential in a mixed asset portfolio. However Lee \& Ting (2009) found some diversification benefits and improvement in performance in an equally weighted portfolio as compared to value weighted portfolio. According to Hudson \& Wilson (2001) found over the period 19872000REITs underperformed both the stock and bond on a risk and return basis. Using the same methodology Ibbotson (2001) found evidence that REITs provide significant positive diversification benefits to a mixed asset portfolio. Ibbotson (2002) reported that on average REITs in a well-diversified asset portfolio improve returns by about $0.8 \%$ between $1992-01$ and about $1.3 \%$ between 1992-03.Webb \& Meyer (2001) examined whether public real estate (REITS) will rebalance or diversify real estate portfolio. These authors found that public real estate has the ability to rebalance the portfolio and concluded that institutional investors should consider holding REITS for purposes other than rebalancing the portfolio.

According to Lee \& Stevenson (2005) REITs diversification benefits were consistent over different investment horizons and the benefits increased as the investment horizon is stretched. These authors also indicated that efficient portfolios allocated large proportion of REITSs with optimal allocation increasing over time. In their study Glascock \& Bond (2006), European public real estate has higher correlation with common stocks, provides additional growth potential and reduced the overall risk of the portfolio. The authors also reported that REITS lagged the equity bull market of the 1990s but outperformed the stocks after the dot com crisis of 2000s. This was supported by Lee (2003) who reported that REITS provided diversification benefits in periods of financial distress. On his part, Lee Stephenson (2010) found the same result but indicated that these benefits change as the REIT industry matures. The author found that before 1999 REITs offered diversification benefits to value stock and large cap growth but negative return benefits. However after 1999, REITs showed return enhancement to large cap stocks than diversification benefits and both returns enhancement and diversification benefits in the case of small cap stocks. The author concluded that the role of REITs in a multi asset portfolio will depend on REITS return performance against other asset classes within the mixed asset portfolio. Similarly Deustche Bank research (2012)indicated that listed real estate provide gradual increase in risk-adjusted returns with high current yields, while contributing to portfolio diversification and delivering attractive total returns. Due to the income distribution requirement, REITs historically had high dividend yields compared to stocks and bonds. Additionally, real estate allocation can increase portfolio diversification because of low correlation with stocks and bond. According to this research report, a REIT can be regarded as a hybrid asset that combines stock-like appreciation characteristics and bond-like yields. However, despite its similarities to certain attributes of both stocks and bonds, the risk and return characteristics of real estate cannot be replicated synthetically, making real estate a unique asset class. (Deusche Bank, research, 2006).

\subsection{Allocating REITs toa Multi Asset Portfolio with Direct Real Estate.}

When an investor incorporates direct real estate in a multi asset portfolio, REITs become operationally redundant on the whole (Glascock et al (2000) and Seiler et al (2001). According to Stevenson (2001) when direct real estate is used as a proxy for real estate allocation, inclusion of REITs does not significantly improve performance. According to Lee \& Stevenson (2005) over the long term horizon REITs have a little role in an optimal mixed asset portfolio containing direct real estate and the REITs allocation seem to diminish or eliminated with inclusion of direct real estate. Mackinnon and Zaman (2009) found evidence that REITs played no or little role in the optimal allocation when both direct real estate and REITs are included in the same portfolio. The authors found that REITS had a weaker mean reversion as compared to core real estate, indicating that REITs displayed the same risk as equities. These studies strongly advocate for direct real estate in building an optimal multi asset based on risk adjusted performance and the reverse is not true. Contrary, the studies of Feldman (1998), Muller \&Muller (2003) and L'Heureux\& Mansour (2004) advocate allocation to both REITs and direct real estate in a multi asset portfolio. According to Mueller \& Mueller (2003) inclusion of both assets strengthen the efficient frontier than inclusion of one or neither. However core real estate show greater effect in low risk and return portfolio whereas REITs improve returns across all risk and return profile. According to Lee Stephen (2010), although REIT show the characteristics of small cap stock, in the long term REITs will perform dismally when real estate allocation is declining because REITs behave more like direct real estate than stock in the longer term. This was partly supported by Kennedy and Baum (2012) who reported that REIT may have greater positive effects on portfolio performance if included in a sub optimal portfolio.

\section{Conclusion And Recommendations}

In general the risk-return characteristics of REITs and direct real estate tend to comparable in the long run than the short run. Although there are common influences underlying returns to real estate and direct real estate, REIT is significantly different in institutional characteristics. REIT is traded in the exchange which has large number of buyers and sellers who trade continuously while direct real estate is infrequently traded. Evidence suggests that REITs on themselves may not be sufficient to provide a strong component of direct real 
estate in a portfolio. Therefore investors should consider including direct real estate in their portfolios because they work together to diversify stock and bond performances and diversify each other. By allocating to both forms investors are able diversify capital market exposure and maintain a balance between liquidity and asset control.

This review indicates that REITs market returns is systematically related to returns to both stock and bond market. REITs are highly correlated to small stock in the short run and in the long run it tends to behave like private real estate than stocks. REITs are also sensitive to changes in interest rates and the sensitivity of REIT depends on whether interest rates are rising or falling and how much debt REIT debt is utilized. These suggest that REIT can be viewed as a hybrid vehicle representing a combination of stock, bond and real estate.

The reviewed studies with limited exceptions indicates that REITs can play a significant role in portfolio construction both as a separate asset class and as an alternative to core real estate. A number of researchers found a significant benefit of adding REITs in the mixed asset portfolio over the long run than in the short run. REITs can be used to enhance returns and reduce risk in a mixed asset portfolio. REITs offer an advantage of diversifying characteristics typical of direct real estate without sacrificing liquidity of their portfolios. In particular it offers potential to exploit inefficiencies that exist in other asset markets and subsectors. However in an optimum mixed asset portfolios containing direct real estate. However diversification benefits tend to diminish during periods of financial distress. Based on this finding the investors should consider timing their portfolio diversification strategies and avoid purchasing REITs in declining markets.

\section{References}

[1] Ang, A., N. Nabar, and S. Wald. Searching for a CommonFactor in Public and Private Real Estate Returns.TheJournal of Portfolio Management, Vol. 39, No. 5 (2013), pp.120-133., 1, 43-55.

[2] CBRE (2007), REITs around Asia 1H 2007, Vol. 12, CBRE Research, Bangkok.

[3] Chandrashekaran, V (1999) Time-Series Properties and Diversification Benefits of REIT Returns,JournalofReal Estate Research, Volume 17, 91-112

[4] Clayton, J. and MacKinnon G. (2000), What Drives Equity REIT Returns?, The RelativeInfluences of Bonds, Stocks, and Real Estate Factors, Paper presented at the AmericanReal Estate and Urban Economics Association meeting, Boston, MA.

[5] Clayton, J. and MacKinnon G. (2001), The Time -Varying Nature of the Link Between REIT, Real Estate and Financial Returns, Journal of Real Estate Portfolio Management,

[6] Clayton, J. and Mackinnon, G (2003) The relative importance of stock, bond, and real estate factors in explaining REIT returns, Journal of Real Estate Finance and Economics, Volume 27, 39-60

[7] Crowe, S., and D. Krisbergh. "Listed property performancesas a predictor of direct real estate performance." Cohen \&Steers Capital Management Inc., Report for the EuropeanPublic Real Estate Association (2009).

[8] Feldman, B.E (2003) Investment Policy for Securitized and Direct Real Estate,Journal of PortfolioManagement, Special Real Estate Issue, 112-21

[9] Fisher, J.D. and Sirmans, C.F. (1994) The Role of Commercial Real Estate in a Multi-assetPortfolio, Journal of Property Management, January

[10] Ghosh, C., Miles, M. and Sirmans, C.F. (1996), “Are REITS stocks?” Real Estate Finance, Vol. 13No. 3, pp. 46-53.

[11] Ghosh, C., Miles, M., and Sirmans, C.F. (1996) Are REITs Stocks?, Journal of Real Estate Finance, 46-53

[12] Giliberto, M. and Mengden, A. (1996) REITs and Real Estate: Two Market Reexamined,

[13] Giliberto, S.M. (1992) The Allocation of Real Estate to Future Mixed-Asset Portfolio,Journal of Real Estate Research, 4, 423-432Glascock,J.L.(2002)Glascock, and Ghosh , (2000)

[14] Glascock, J and Bond (2006) Performance and Diversification Benefits of European Real Estate Securities, European Public Real Estate Association,www.epra.org

[15] Glascock, J.L., Lu, C. and So, R.W. (2000) Further Evidence on the Integration of REIT, Bond, and Stock Returns, Journal of Real Estate Finance and Economics, 20, p1-9

[16] Glascock,J.L. and Ghosh , (2000)

[17] Gyourko, J., (2003) Real Estate Returns in Public and Private Markets, Zell/Lurie Real Estate Center, Working Paper 470

[18] Hemel, E., Sakwa, S. and Bhattacharjee, R. (1995) Interest Rate Sensitivity of REITs:Myth and Reality, Morgan Stanley: U.S. Investment Research Paper, 1585 Broadway,New York, New York 1003 6-8293.

[19] Hoesli, M. and Oikarinen, E (2012) Are REITs real estate? Evidence from international sector level data, Swiss Finance Institute Research Paper Series Number 12-15

[20] Kok, K.K. and Khoo, K.L. (1995), "Performance of property trusts in the Kuala Lumpur stockexchange", Capital Markets Review, Vol. 3, pp. 1-19.

[21] Kuhle, J (1987) Portfolio Diversification and Return Benefits-Common Stocks vs. Real Estate Investment Trusts (REITs), Journal of Real Estate Research, Volume 2, 1-9

[22] L'Heuruex, S. and Mansour, A. (2004) The Role of Public and Private Real estate in a Diversified Multi -Asset Portfolio, A Paper Presented at the American Real Estate SocietyMeeting Captiva Island, Florida

[23] Lee, C.L. (2009), "Downside beta and valuation-based property returns", Pacific Rim PropertyResearch Journal, Vol. 15 No. 2.

[24] Lee, S. "The changing benefit to the mixed-asset portfolio."The Journal of Real Estate Portfolio Management, Vol. 16, No. 3 (2010), pp. 201-215. 
[25] Lee, S. and S. Stevenson. "The case for REITs in the mixed asset portfolio in the short and long run." The Journal ofReal Estate Portfolio Management, Vol. 11, No. 1 (2005), pp. 55-80.

[26] Lee, S. and Stevenson, S. (2005), "The case for REITs in the mixed-asset portfolio in the short andlong run", Journal of Real Estate Portfolio Management, Vol. 11 No. 1, pp. 55-80.

[27] Lee, S. and Stevenson, S. (2005). The Case for REITs in the Mixed- Asset Portfolio in the Short and Long Run, Journal of Real Estate Portfolio Management, 11, 55-80.

[28] Lee, S.L (2010) The Changing Benefit of REITs to the Mixed-Asset Portfolio,Journal of Real Estate PortfolioManagement, Volume 16, Number 3, 201-215

[29] Lee, S.L (2010) The Changing Benefit of REITs to the Mixed-Asset Portfolio, Journal of Real Estate PortfolioManagement, Volume 16, Number 3, 201-215

[30] Liang, Y. and McIntosh, W. (1998) REIT Style and Performance, Journal of Real EstatePortfolio Management,4, 6978

[31] Liang, Y. and McIntosh, W.(1998) REIT style and performance, Journal of Real Estate Portfolio Management, Volume 4, Number 1, 69-78

[32] Ling, D. and Naranjo, A. (2012) Returns, Volatility, and Information Transmission Dynamics in Public and Private Real Estate Markets, Bergstrom Centre for Real Estate Studies Working Paper, August

[33] Liu, C.H. and Mei, J. (1992) The Predictability of Returns on Equity REITs and their Co-Movement with Other Assets, Journal of Real Estate Finance and Economics, Volume 5, 401-418

[34] Mackinnon, G. H and Zaman, A.A(2009) Real estate for the long term: the effect of return predictability on longhorizon allocations, Real Estate Economics, Volume 37, Issue 1, 117-153

[35] Moss, A., and A. Baum. "Are listed real estate stocksmanaged as a part of the real estate allocation?" EPRAResearch Paper (2013).

[36] Mueller, A.G and Mueller, G.R (2003) Public and Private Real Estate in the Mixed-Asset Portfolio. Journal ofReal Estate Portfolio Management, Volume 9, 193-203

[37] Mueller, G.R. Pauley, K. and Morrill, W.A. (1994) Should REITs be included in a mixed-asset portfolio? RealEstate Finance, Volume 11, Number 1, 23-28

[38] Myer, F.C. and Webb, J.R. (1993) Return Properties on Equity REITs, Common Stocks and Commercial Real Estate: A Comparison, Journal of Real Estate Research, 8, 87-106

[39] Nelling, E. and Gyourko, J. (1998) The Predictability of Equity REIT returns, Journal ofReal Estate Research, 3, 25 $1-268$.

[40] Newell, G., Ting, K.H. \&Acheampong, P. (2002) Listed Property Trusts in Malaysia , Journal of Real Estate Literature, Vol. 10:1, 109-18

[41] Newell, G. (2005a), "The changing dynamics of Australian commercial property portfolios" Australian Property Journal, Vol. 38 No. 7 , pp. 553-8.

[42] Newell, G. (2005b), "Factors influencing the performance of listed property trusts", Pacific RimProperty Research Journal, Vol. 11 No. 2, pp. 211-27.

[43] Newell, G. and Acheampong, P. (2001), "The dynamics of the australian property trust marketrisk and correlation profile”, Pacific Rim Property Research Journal, Vol. 7 No. 4, pp. 259-70.

[44] Newell, G. (2007), et al

[45] Oikarinen, E., Hoesli, M. and Serrano, C (2011) The long-run dynamics between direct and securitized real estate, Journal of Real Estate Research, Volume 33, Issue 1, 73-103Real Estate Finance,

[46] Sanders, A.B. (1998) The Historical Behavior of REIT Returns: A Capital Market Perspective, in Garrigan, R.T. and Parsons, J.F.C. (eds.), Real Estate Investment Trusts, McGraw-Hill

[47] Seiler, M.J., Webb, J.R. and Meyer, N.F.C. (2001) Can Private Real Estate Portfolios be Rebalanced/Diversified using Equity REIT Shares, Journal of Real Estate PortfolioManagement,7,

[48] Simon, S and Wing, L (2009) The Effect of the Real Estate Downturn on the Link between REITs and the Stock Market, Journal of Real Estate Portfolio Management, Volume 15, Number 3, 211-219

[49] Stevenson, S. (2001). The Long-Term Advantages of Incorporating Indirect Securities in Direct Real Estate Portfolios, Journal of Real Estate Portfolio Management, 7, 5-16.

[50] Stevenson, S. (2001). The Long-Term Advantages of Incorporating Indirect Securities in Direct Real Estate Portfolios, Journal of Real Estate Portfolio Management, 7, 5-16.

[51] Ting, K.H. (2002), "Listed property companies in Malaysia: a comparative performance analysis",paper presented at the 7th Pacific Rim Real Estate Society Conference, Christchurch

[52] Westerheid, P(2006) Cointegration of Real Estate Stocks and REITs with Common Stocks, Bonds and Consumer Price Inflation: and international comparison, Centre for European Economic Research, Discussion Paper Number: 06-057

[53] Wilson, P.J. and Okunev, J. (1996), "Evidence of segmentation in domestic and internationalproperty markets", Journal of Property Finance, Vol. 7 No. 4, pp. 78-97

[54] Yunus, N., Hansz, A., and Kennedy, P.J (2012) Dynamic Interactions between Private and Public Real Estate Markets: Some International Evidence, Journal of Real Estate Finance and Economics, Volume 45, Number 4, 1021-1040

[55] Ziering, B. Liang, D.C. and McIntosh, W. (1997) REIT Correlations with Capital market Indexes: Separating Signal from Noise, Real Estate Finance, 4, 61-67 